\title{
Synthesis of 5-alkoxyindolizines from oxazolo[3,2-a]pyridinium salts
}

\author{
Eugene V. Babaev, ${ }^{* \dagger}$ Andrey V. Efimov, Alexander A. Tsisevich, \\ Aleksandra A. Nevskaya and Victor B. Rybakov
}

Department of Chemistry, M. V. Lomonosov Moscow State University, 119992 Moscow, Russian Federation. Fax: +7 495939 3020; e-mail: babaev@org.chem.msu.ru

DOI: $10.1016 /$ j.mencom.2007.03.027

A new route to poorly available 5-alkoxyindolizines has been developed by reaction of oxazolo[3,2-a]pyridinium salts with sodium alkoxides; the structures of three indolizines and one parent salt have been confirmed by X-ray diffraction analysis.

The indolizine ring is isomeric and isostructural to indole, and substituted indolizines are frequently prepared as bioisosters of biologically active indole derivatives. A well-known class of psychotropic indole compounds (e.g., psillocine, psylocibine and pindolole) belongs to the family of 5-hydroxy(alkoxy)indoles. An isostructural class of indolizines bearing 5-OR group ( $\mathbf{A}$ in Scheme 1) may serve as the biomimetics of such indoles. This class can be designed by a mental rearrangement of the indole ring nitrogen into bridgehead positions.<smiles>[R]Oc1cccc2cccn12</smiles>

$\mathbf{A}$<smiles>[R]C1=Cc2cc(C)c(C#N)c(=O)n2C1</smiles><smiles></smiles>

B<smiles>[R]c1cc2cc(C)c(C#N)c([X])n2c1</smiles>

Scheme 1

The entire class of 5-alkoxy(hydroxyl)indolizines is poorly investigated since there is lack of synthetic methodologies leading to this scaffold. Rare examples of preparation of the members of class A include their synthesis from pyrrole derivatives $^{1-3}$ and by means of photolytic C-5 oxidation of the indolizine ring. ${ }^{4}$ Structure $\mathbf{B}$ with the desired motif was prepared via 1,3-dipolar cycloaddition. ${ }^{5}$ The most common strategy to indolizine ring (the Chichibabin cyclization) failed for the case of 6-methoxy-2-picoline. ${ }^{6}$ It is, however, possible to annelate the pyrrole ring to pyridine by condensation of the Guresci pyridone with $\alpha$-bromoketones ${ }^{7,8}$ leading to 5 -indolizinones $\mathbf{C}$, which are stable tautomers of desired 5-hydroxyindolizines D. We found ${ }^{9}$ that pyridone-like derivatives $\mathbf{C}$ can be converted into 5-chloroindolizines $\mathbf{E}$, which react with $\mathrm{MeONa}$ leading to 5-methoxy-6-cyanoindolizines F. However, simple 5-alkoxyindolizines A (without other substituents in the pyridine ring) remain unknown.

We reported an efficient strategy ${ }^{10-12}$ to build the indolizine ring by a somewhat unusual conversion of oxazolo[3,2-a]-

$\uparrow$ A lecturer at the Higher Chemical College of the RAS. pyridinium salts $\mathbf{G}$ (route $a$ in Scheme 2). This reaction allowed us to prepare 5-dialkylaminoindolizines H. Recently, ${ }^{13}$ this methodology has attracted attention in industrial chemistry as a source of a library of 5-substituted indolizines with potential bioactivity. However, only secondary amines are suitable for such a transformation, and with primary amines (route $b$ ) salts $\mathbf{I}$ were formed instead of indolizines.

Therefore, it is unclear which other nucleophiles are suitable for this new strategy of indolizine synthesis from oxazolopyridines. Furthermore, the ring system of salts $\mathbf{G}$ may undergo alternative modes of ring opening depending on the group $\mathrm{R}$ and the nature of the nucleophile. Thus, salts $\mathbf{G}$ with $\mathrm{R}=\mathrm{H}$ react with secondary amines with pyridine ring opening (route $c^{11}$ ), whereas with alkoxide the $\mathrm{C}(2)-\mathrm{O}$ bond cleavage was observed (route $d^{14}$ ). In this paper, we studied the direction of the reaction of salts $\mathbf{G}(\mathrm{R}=\mathrm{Me})$ with alkoxides to test the synthesis of 5-alkoxyindolizines A.

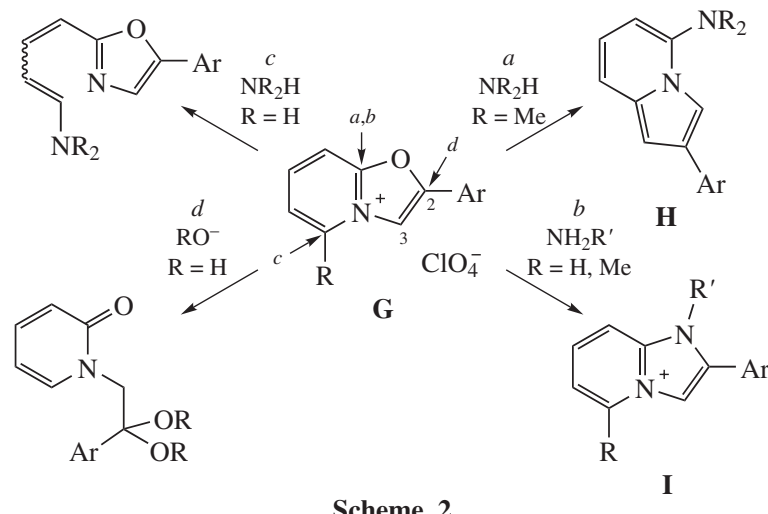

We found that the reactions of salts $\mathbf{1 a}-\mathbf{c}$ with sodium methoxide smoothly led to previously unknown 5-methoxyindolizines 2a-c. Variation of the nature of alcohol was performed for salt 1a, and its reactions with sodium ethoxide and sodium isopropoxide led to corresponding 5-alkoxyindolizines $\mathbf{3}, \mathbf{4}$. All reactions were usually complete in one or two days at room temperature (additional heating decreased the yields and purity of the products).

Compounds 2-4 gave a positive Erlich test with $p$-dimethylaminobenzaldehyde (deep blue colour typical of indolizines). In the ${ }^{1} \mathrm{H}$ NMR spectra of indolizines (Table 1), two new aromatic singlets of the formed pyrrole ring and the peaks of the RO group were observed (whereas the methyl group, which was initially present in salts $\mathbf{1}$, disappeared), thus clearly confirming 
Table 1 Characteristics of 5-alkoxyindolizines.

\begin{tabular}{|c|c|c|c|c|c|c|c|c|c|c|c|}
\hline \multirow{2}{*}{ Compound } & \multirow{2}{*}{$\begin{array}{l}\text { Yield } \\
(\%)\end{array}$} & \multirow{2}{*}{$\mathrm{Mp} /{ }^{\circ} \mathrm{C}$} & \multicolumn{7}{|c|}{${ }^{1} \mathrm{H}$ NMR $\left(\left[{ }^{2} \mathrm{H}_{6}\right] \mathrm{DMSO}\right) /$ Substituents ${ }^{a}$} & \multicolumn{2}{|c|}{$\mathrm{m} / \mathrm{z}(\%)$} \\
\hline & & & 1-H (s) & 3-H (s) & 6-H (s) & 7-H [R] & $8-\mathrm{H}(\mathrm{s})$ & $5-\mathrm{OR}$ & $2-\operatorname{Ar}(\mathrm{m})$ & {$\left[\mathrm{M}^{+}\right]$} & {$[\mathrm{M}-\mathrm{R}]$} \\
\hline$\overline{\mathbf{2 \mathbf { a } ^ { b }}}$ & 66 & $188-189$ & 6.90 & 7.96 & 6.03 & $6.81(\mathrm{dd})$ & 7.10 & 4.14 & $8.24,8.03$ & $268(97)$ & $253(100)$ \\
\hline $2 b$ & 39 & $202-204$ & 6.78 & 7.95 & 5.95 & {$[2.28]$} & 6.88 & 4.07 & $8.22-8.20,8.03-8.01$ & $282(96)$ & $267(100)$ \\
\hline $2 c$ & 79 & $177-179$ & 6.61 & 7.73 & 5.77 & \multicolumn{2}{|c|}{$[2.64(\mathrm{~m})]^{c}$} & 4.03 & $7.71-7.68,7.55-7.52$ & $355(100)$ & $340(89)$ \\
\hline 3 & 43 & $196-197$ & 6.80 & 7.88 & 5.97 & $6.75(\mathrm{~m})$ & 7.04 & $4.37,1.57$ & $8.21,7.94$ & $282(84)$ & $253(100)$ \\
\hline 4 & 63 & $178-179$ & 6.79 & 7.86 & 5.99 & $6.75(\mathrm{~m})$ & 7.03 & $4.88,1.51$ & $8.24,8.03$ & $296(20)$ & $254(100)$ \\
\hline
\end{tabular}

${ }^{a}$ According to the numbering of the indolizine ring. ${ }^{b}$ Solvent $\left(\mathrm{CD}_{3}\right)_{2} \mathrm{CO} .{ }^{c} 1.80 \mathrm{ppm}(\mathrm{m})$ for $\left(\mathrm{CH}_{2}\right)_{n}$.<smiles></smiles>

1a,b

\begin{tabular}{l|l} 
RONa \\
ROH
\end{tabular}<smiles>[R]Oc1cc([R])cc2cc(-c3ccc([N+](=O)[O-])cc3)cn12</smiles>

$\mathbf{2 a}, \mathbf{b}, \mathbf{3}, 4$

$2 \mathrm{R}=\mathrm{Me}$

$3 \mathrm{R}=\mathrm{Et}$

$4 \mathrm{R}=\mathrm{Pr}^{\mathrm{i}}$

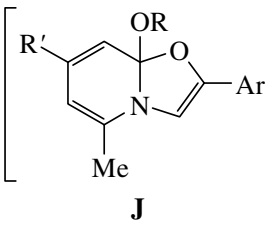<smiles>Cc1c2c(cc3oc(-c4ccc(Br)cc4)c[n+]13)CCCC2</smiles>

1c

$$
\begin{aligned}
& \mathrm{MeONa} \\
& \mathrm{MeOH}
\end{aligned}
$$<smiles>COc1cc2c(c3cc(-c4ccc(Br)cc4)cn13)CCCC2</smiles>

2c

1, 2: a $R^{\prime}=H$

3, 4: $\quad \mathrm{R}^{\prime}=\mathrm{H}$

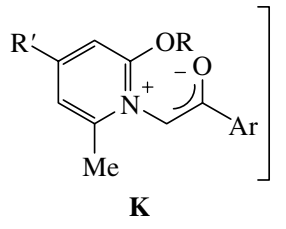

Scheme 3

the structures of 2-4. The mass spectra of 5-alkoxyindolizines contained the molecular ion; however, the most intense peaks were $[\mathrm{M}-\mathrm{R}]$ corresponding to the cleavage of an alkoxy group. The structures of 5-alkoxyindolizines $\mathbf{2 a}, \mathbf{2 c}$ and $\mathbf{4}$ were finally confirmed by X-ray analysis (Figure 1). In the structures of all indolizines clear alternation of single and double bonds along the bicyclic perimeter was observed indicating a well-known tetraene-like character of the indolizine nucleus.

The reaction mechanism most probably involves the attack of an RO anion at the carbon bridgehead position giving adduct $\mathbf{J}$.<smiles>[R]c1cc(OC)nc([R])c1[R]</smiles>

$5 \mathbf{a}-\mathbf{c}$<smiles>[Y1]C(=O)Cn1c([N+]([R])=O)c([R])c([R])cc1=O</smiles>

6a-c<smiles>[R]c1cc2oc([Al])c[n+]2c(C)c1[R]</smiles>

1a-c

$$
\begin{array}{rrr}
\text { 1, 5, 6: } & \text { a } \mathrm{R}=\mathrm{R}^{\prime}=\mathrm{H} & \mathbf{1 , 6}, \mathbf{a}, \mathbf{b} \mathrm{Ar}=p-\mathrm{NO}_{2} \mathrm{C}_{6} \mathrm{H}_{4} \\
\text { b } \mathrm{R}=\mathrm{H}, \mathrm{R}^{\prime}=\mathrm{Me} & \text { c } \mathrm{Ar}=p-\mathrm{BrC}_{6} \mathrm{H}_{4} \\
\text { c } \mathrm{R}+\mathrm{R}^{\prime}=\left(\mathrm{CH}_{2}\right)_{4} & &
\end{array}
$$

Scheme 4
Further cleavage of the oxazole ring gave rise to ylide structure $\mathbf{K}$, which undergoes final closure and dehydration to the pyrrole ring. Interestingly, in the reaction of salt $1 \mathbf{a}$ with $\mathrm{Bu}^{\mathrm{t} O N a}$ (or $\mathrm{Bu}^{\mathrm{t}} \mathrm{OK}$ ), no indolizine was formed, and the starting material was converted into unidentified tar. Probably, the more basic tert-butoxide ion may cause deprotonation of the potentially acidic 5-Me group of salt 1a followed by side chain reactions. No reaction of salt 1a with $\mathrm{PhONa}$ was observed (maybe due to a lower nucleophilicity of the phenolate anion). The nature of the electron-withdrawing group at the phenyl group in the 2-position is crucial to the stability of 5-alkoxyindolizines. Thus, indolizines $\mathbf{2 a}, \mathbf{b}, \mathbf{3}, \mathbf{4}$ with the 2-(p-nitrophenyl) group were stable, whereas compound $\mathbf{2 c}$ with the 2-( $p$-bromophenyl) residue decomposed on keeping. Attempts to prepare other oxazolopyridinium salts with 2 -[ $p$-bromo(chloro)phenyl] substituents in reactions with alkoxides led to very unstable products.

Parent salts 1 were prepared by the phenacylation of methoxypyridines $\mathbf{5 a}-\mathbf{c}$ followed by the cyclocondensation
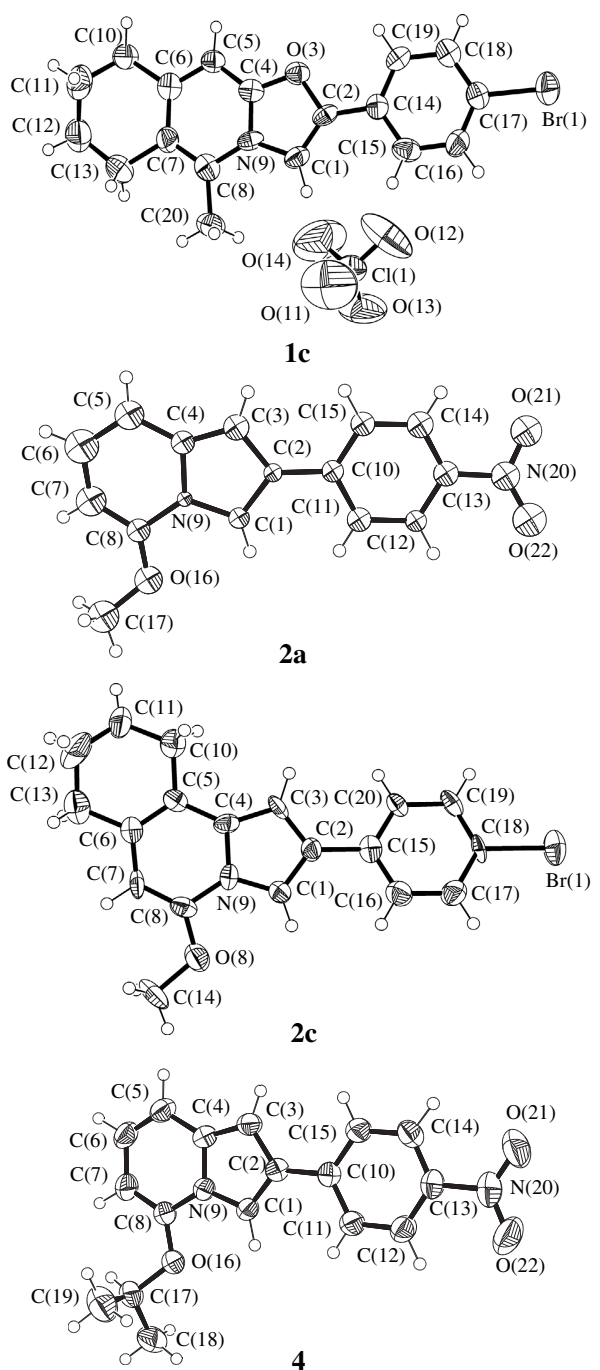

Figure 1 X-ray crystal structures of compounds $1 c, 2 a, 2 c$ and 4. 
of $\mathrm{N}$-phenacylpyridones $\mathbf{6 a - c}$ (using $\mathrm{H}_{2} \mathrm{SO}_{4}$ as a dehydrating agent) (Scheme 4) and separated as perchlorates. The spectral changes from pyridones $\mathbf{6}$ to oxazolo[3,2-a]pyridinium salts $\mathbf{1}$ clearly confirm the closure of an aromatic ring: the singlet of the $\mathrm{CH}_{2}$ group disappeared in salts $\mathbf{1}$, and a new aromatic singlet $(1 \mathrm{H})$ of the oxazole fragment is observed at $9.5-9.7 \mathrm{ppm}$. The structure of salt $1 \mathbf{c}$ was confirmed by X-ray data ${ }^{\S}$ (see Figure 1 ).

This work was supported by the Russian Foundation for Basic Research (project no. 04-03-32823-a).

\section{References}

1 B. R. Yerxa and H. W. Moore, Tetrahedron Lett., 1992, 33, 7811.

2 F. Gavina, A. M. Costero, M. R. Andreu and M. D. Ayet, J. Org. Chem., 1991, 56, 5417

3 M. Kim and E. Vedejs, J. Org. Chem., 2004, 69, 6945.

4 Y. Li, H. Y. Hu, J. P. Ye, H. K. Fun, H. W. Hu and J. H. Xu, J. Org. Chem., 2004, 69, 2332.

5 A. Padwa, D. J. Austin, L. Precedo and L. Zhi, J. Org. Chem., 1993, $\mathbf{5 8}, 1144$.

6 E. V. Babaev, A. V. Efimov and D. A. Maiboroda, Khim. Geterotsikl. Soedin., 1995, 1104 [Chem. Heterocycl. Compd. (Engl. Transl.), 1995, 31, 962].

\$ ${ }^{1} \mathrm{H}$ NMR spectra were recorded on a Bruker AC 400 instrument. The syntheses of compounds $1 \mathbf{1 a}, \mathbf{5 a}$ and $\mathbf{6 a}$ were described elsewhere; ${ }^{10,11}$ compound $\mathbf{5 b}$ was obtained according to a published procedure. ${ }^{15}$

3-Methoxy-1-methyl-5,6,7,8-tetrahydroisoquinoline 5c was prepared by the alkylation of the Ag salt of the corresponding pyridone with MeI using a protocol ${ }^{16}$ for pyrid-2-one. Yield, $73 \%$, mp 39-40 ${ }^{\circ} \mathrm{C}$. ${ }^{1} \mathrm{H}$ NMR ([ $\left.\left.{ }^{2} \mathrm{H}_{6}\right] \mathrm{DMSO}\right) \delta: 6.23(\mathrm{~s}, 1 \mathrm{H}, 4-\mathrm{H}), 3.78(\mathrm{~s}, 3 \mathrm{H}, 3-\mathrm{OMe}), 2.66(\mathrm{t}, 2 \mathrm{H}$, $\left.5-\mathrm{CH}_{2}, J_{5,6} 6.0 \mathrm{~Hz}\right), 2.53\left(\mathrm{t}, 2 \mathrm{H}, 8-\mathrm{CH}_{2}, J_{7,8} 6.0 \mathrm{~Hz}\right), 2.28$ (s, 3H, 1-Me), $1.75\left[\mathrm{~m}, 4 \mathrm{H}, 6,7-\left(\mathrm{CH}_{2}\right)_{2}\right]$. Compound $\mathbf{5 c}$ was involved into the next step without further purification.

Reaction of 2-methoxypyridines $\mathbf{5 b}, \mathbf{c}$ with phenacyl bromides. A solution of 2-methoxypyridine $(25 \mathrm{mmol})$ and phenacyl bromide $(20 \mathrm{mmol})$ in $40 \mathrm{ml}$ of MeCN was refluxed for 30-40 h. The precipitate was filtered off and recrystallised from acetonitrile.

4,6-Dimethyl-N-(4-nitrophenacyl)pyridone $\mathbf{6 b}$ was prepared from pyridine 5b and $p$-nitrophenacyl bromide. Yield $39 \%$; mp $182-184{ }^{\circ} \mathrm{C} .{ }^{1} \mathrm{H}$ NMR ( $\left.\left[{ }^{2} \mathrm{H}_{6}\right] \mathrm{DMSO}\right) \delta: 8.40-8.38(\mathrm{~m}, 2 \mathrm{H}, \mathrm{Ar}), 8.30-8.28(\mathrm{~m}, 2 \mathrm{H}, \mathrm{Ar}), 6.12(\mathrm{~s}$, 1H, 3-H), 6.07 (s, 1H, 5-H), 5.57 (s, 2H, NCH $), 2.23$ (s, 2H, 6-Me), 2.12 (s, 3H, 4-Me). MS, m/z (\%): 286 (19) $\left[\mathrm{M}^{+}\right], 150$ (14), 136 (48), 108 (100).

$\mathrm{N}$-(4-Bromophenacyl)-1-methyl-5,6,7,8-tetrahydroisoquinoline-3-one $\mathbf{6 c}$ was prepared from pyridine $\mathbf{5 c}$ and $p$-bromophenacyl bromide. Yield $38 \%$; mp 232-234 ${ }^{\circ} \mathrm{C} .{ }^{1} \mathrm{H}$ NMR $\left(\left[{ }^{2} \mathrm{H}_{6}\right] \mathrm{DMSO}\right) \delta: 8.03-8.00(\mathrm{~m}, 2 \mathrm{H}, \mathrm{Ar})$, 7.71-7.68 (m, 2H, Ar), $6.03(\mathrm{~s}, 1 \mathrm{H}, 4-\mathrm{H}), 5.56\left(\mathrm{~s}, 2 \mathrm{H}, \mathrm{NCH}_{2}\right), 2.64(\mathrm{t}$, $\left.2 \mathrm{H}, 5-\mathrm{CH}_{2}, J_{5,6} 6.0 \mathrm{~Hz}\right), 2.54\left(\mathrm{t}, 2 \mathrm{H}, 8-\mathrm{CH}_{2}, J_{7,8} 6.0 \mathrm{~Hz}\right), 2.13(\mathrm{~s}, 3 \mathrm{H}$, 1-Me), 1.76 [m, 4H, 6,7-( $\left.\left.\mathrm{CH}_{2}\right)_{2}\right]$. Found (\%): C, 60.04; H, 5.13; N, 3.87. Calc. for $\mathrm{C}_{18} \mathrm{H}_{18} \mathrm{BrNO}_{2}(\%)$ : C, 60.01; H, 5.04; N, 3.89 .

Perchlorates $\mathbf{1 b}, \mathbf{c}$ were prepared according to the described procedure ${ }^{11}$ for perchlorate 1a.

5,7-Dimethyl-2-(4-nitrophenyl)oxazolo[3,2-a]pyridinium perchlorate 1b: yield 83\%; mp 272-274 ${ }^{\circ} \mathrm{C}$. ${ }^{1} \mathrm{H}$ NMR $\left(\left[{ }^{2} \mathrm{H}_{6}\right] \mathrm{DMSO}\right) \delta: 9.68(\mathrm{~s}, 1 \mathrm{H}$, 3-H), 8.54-8.50 (m, 2H, Ar), 8.31-8.27 (m, 2H, Ar), 8.24 (s, 1H, H-8), 7.77 (s, 1H, H-6), 2.86 (s, 3H, 5-Me), 2.67 (s, 3H, 7-Me). Found (\%): C, 49.08; $\mathrm{H}, 3.46 ; \mathrm{N}, 7.37$. Calc. for $\mathrm{C}_{15} \mathrm{H}_{13} \mathrm{~N}_{2} \mathrm{O}_{7} \mathrm{Cl}(\%)$ : C, 48.86; H, 3.55; N, 7.60.

2-(4-Bromophenyl)-5-methyl-6,7,8,9-tetrahydrooxazolo[3,2-a]isoquinolinium perchlorate 1c: yield $90 \%$; mp $280-282{ }^{\circ} \mathrm{C} .{ }^{1} \mathrm{H} \mathrm{NMR}\left(\mathrm{CF}_{3} \mathrm{COOH}+\right.$ $\left.\left[{ }^{2} \mathrm{H}_{6}\right] \mathrm{DMSO}\right) \delta: 9.42(\mathrm{~s}, 1 \mathrm{H}, 3-\mathrm{H}), 7.96(\mathrm{~s}, 1 \mathrm{H}, 10-\mathrm{H}), 7.92-7.89(\mathrm{~m}, 2 \mathrm{H}$, Ar), 7.81-7.78 (m, 2H, Ar), 3.05 (t, 2H, 9- $\left.\mathrm{CH}_{2}, J 6.0 \mathrm{~Hz}\right), 2.84(\mathrm{t}, 2 \mathrm{H}$, 6- $\left.\mathrm{CH}_{2}, J 6.0 \mathrm{~Hz}\right), 2.74(\mathrm{~s}, 3 \mathrm{H}, 5-\mathrm{Me}), 1.81\left[\mathrm{~m}, 4 \mathrm{H}, 7,8-\left(\mathrm{CH}_{2}\right)_{2}\right]$. Found (\%): C, 48.82; H, 3.68; N, 3.21. Calc. for $\mathrm{C}_{18} \mathrm{H}_{17} \mathrm{ClBrNO}_{5}(\%)$ : C, 48.84; $\mathrm{H}, 3.87$; N, 3.16 .

Reaction of perchlorates $\mathbf{1}$ with sodium alcoholates (general procedure). Perchlorate $(0.5 \mathrm{mmol})$ was added to a solution of MeONa in methanol (prepared from $7.4 \mathrm{mmol}$ of sodium and $10 \mathrm{ml}$ of anhydrous $\mathrm{MeOH}$ ). The reaction mixture was kept for $16 \mathrm{~h}$ at room temperature. The precipitate was filtered off and recrystallised from acetonitrile. All compounds gave satisfactory elemental analysis data. Crystal structures of the compounds $\mathbf{2 a}, \mathbf{c}$ and $\mathbf{4}$ are shown in Figure 1. Other characteristics of 5-alkoxyindolizines $\mathbf{2 - 4}$ are given in Table 1 .
7 K. Gevald and H. J. Jansch, J. Prakt. Chem., 1976, 318, 313.

8 C. F. Lin, Y. F. Lin, Y. C. Lo, K. T. Chen and T. L. Su, Heterocycles, 2000, 53, 15.

9 E. V. Babaev, N. I. Vasilevich and A. S. Ivushkina, Beilstein J. Org. Chem., 2005, 1, 9.

10 E. V. Babaev and A. V. Efimov, Khim. Geterotsikl. Soedin., 1997, 998 [Chem. Heterocycl. Compd. (Engl. Transl.), 1997, 33, 964].

11 E. V. Babaev, A. V. Efimov, D. A. Maiboroda and K. Jug, Eur. J. Org. Chem., 1998, 193.

12 E. V. Babaev, Lectures in Heterocyclic Chemistry, 2000, 37, 519.

13 P. Tielmann and C. Hoenke, Tetrahedron Lett., 2006, 47, 261.

14 E. V. Babaev, S. V. Bozhenko, D. A. Maiboroda, V. B. Rybakov and S. G. Zhukov, Bull. Soc. Chim. Belg., 1997, 11, 631.

15 P. Dembech, A. Ricci, G. Seconi and P. Vivarelli, J. Chem. Soc. B, 1971, 2299.

16 G. C. Hopkins, J. P. Jonak and H. J. Minnermeyer, J. Am. Chem. Soc., 1967, 32, 4040.

17 G. M. Sheldrick, SHELX97. Program Complex for the Crystal Structure Solutiom and Refinement, University of Göttingen, Germany, 1997.

Received: 30th November 2006; Com. 06/2832

$\S$ Crystallographic data. All X-ray intensities were measured using a CAD4 diffractometer at 293(2) $\mathrm{K}[\lambda(\mathrm{MoK} \alpha)$ radiation]. All structures were solved by a direct method and refined by a full-matrix least-squares technique against $F^{2}$ in an anisotropic approximation (for $\mathbf{2 a}$, in an isotropic approximation). The hydrogen atoms were placed in calculated positions and refined in an isotropic approximation in a riding model (1c, 2a,c) and found from the difference Fourier maps and refined in an isotropic approximation (4). All calculations were performed using SHELX-97. ${ }^{17}$

For 1c: crystals of $\mathrm{C}_{18} \mathrm{H}_{17} \mathrm{BrClNO}_{5}$ are monoclinic, space group $P 2_{1} / n$, $a=12.099(3), b=8.446(3)$ and $c=18.265(5) \AA, \beta=107.61(2)^{\circ}, V=$ $=1778.9(9) \AA^{3}, Z=4, \quad M=442.69, d_{\text {calc }}=1.653 \mathrm{~g} \mathrm{~cm}^{-3}, \mu(\mathrm{MoK} \alpha)=$ $=2.491 \mathrm{~cm}^{-1}$. Intensities of 1635 reflections were measured $[\omega$-scans with $120 \mathrm{~s}$ exposure per reflection, $\theta<26^{\circ}$ ] and 1574 independent reflections $\left(R_{\text {int }}=0.0297\right)$ were used in the further refinement. Refinement converged to $R_{1}=0.0444$ was calculated against $F^{2}$ for 1574 observed reflections with $I>2 \sigma(I)$.

For 2a: crystals of $\mathrm{C}_{15} \mathrm{H}_{12} \mathrm{~N}_{2} \mathrm{O}_{3}$ are monoclinic, space group $P 2{ }_{1} / c$, $a=6.855(2), \quad b=7.096(2)$ and $c=25.978(6) \mathrm{A}, \quad \beta=94.96(2)^{\circ}, \quad V=$ $=1259.0(6) \AA^{3}, Z=4, \quad M=268.27, d_{\text {calc }}=1.415 \mathrm{~g} \mathrm{~cm}^{-3}, \mu(\mathrm{MoK} \alpha)=$ $=0.101 \mathrm{~cm}^{-1}$. Intensities of 2261 reflections were measured [ $\omega$-scans with $120 \mathrm{~s}$ exposure per reflection, $\theta<20^{\circ}$ ], and 2207 independent reflections were used in the further refinement. Refinement converged to $R_{1}=0.1770$ was calculated against $F^{2}$ for 282 observed reflections with $I>2 \sigma(I)$.

For 2c: crystals of $\mathrm{C}_{19} \mathrm{H}_{18} \mathrm{BrNO}$ are monoclinic, space group $P 2_{1} / c$, $a=12.516(5), b=6.688(5)$ and $c=19.104(5) \AA, \beta=90.92(2)^{\circ}, V=$ $=1599.0(14) \AA^{3}, Z=4, M=356.25, d_{\text {calc }}=1.480 \mathrm{~g} \mathrm{~cm}^{-3}, \mu(\mathrm{MoK} \alpha)=$ $=2.572 \mathrm{~cm}^{-1}$. Intensities of 1505 reflections were measured [ $\omega$-scans with $120 \mathrm{~s}$ exposure per reflection, $\theta<25^{\circ}$ ] and 1443 independent reflections were used in the further refinement. Refinement converged to $R_{1}=0.0537$ was calculated against $F^{2}$ for 878 observed reflections with $I>2 \sigma(I)$.

For 4: crystals of $\mathrm{C}_{17} \mathrm{H}_{16} \mathrm{~N}_{2} \mathrm{O}_{3}$ are monoclinic, space group $P 2_{1} / c$, $a=11.1579(2), b=11.2795(4)$ and $c=12.2594(3) \AA, \beta=105.63(2)^{\circ}$, $V=1485.86(7) \AA^{3}, Z=4, M=296.32, d_{\text {calc }}=1.325 \mathrm{~g} \mathrm{~cm}^{-3}, \mu(\operatorname{MoK} \alpha)=$ $=0.092 \mathrm{~cm}^{-1}$. Intensities of 3411 reflections were measured $[\omega$-scans with $60 \mathrm{~s}$ exposure per reflection, $\theta<28^{\circ}$ ] and 3263 independent reflections were used in the further refinement. Refinement converged to $R_{1}=0.0566$ was calculated against $F^{2}$ for 2067 observed reflections with $I>2 \sigma(I)$.

Atomic coordinates, bond lengths, bond angles and thermal parameters have been deposited at the Cambridge Crystallographic Data Centre (CCDC). These data can be obtained free of charge via www.ccdc.cam.uk/ conts/retrieving.html (or from the CCDC, 12 Union Road, Cambridge CB2 1EZ, UK; fax: +44 1223336 033; or deposit@ccdc.cam.ac.uk). Any request to the $\mathrm{CCDC}$ for data should quote the full literature citation and CCDC reference numbers 639127-639130 for 1c, 2a, 2c and 4, respectively. For details, see 'Notice to Authors', Mendeleev Commun., Issue 1, 2007. 